\title{
Çalışmayan Ev Kadınlarının Mutluluk ve Kişisel Gelişim Yönelimi Düzeylerinin İncelenmesi
}

\author{
Fulya YÜKSEL ŞAHINN ${ }^{1}$, Tülay TAŞKIN ${ }^{2}$
}

${ }^{1}$ Eğitim Bilimleri Bölümü, Eğitim Fakültesi, Yıldız Teknik Üniversitesi, İstanbul, Türkiye

${ }^{2}$ Eğitim Bilimleri Anabilim Dalı, Sosyal Bilimler Enstitüsü, Yıldız Teknik Üniversitesi, İstanbul, Türkiye

Sorumlu Yazar: Fulya YÜKSEL ŞAHIN, fusahin@yildiz.edu.tr

Makale Türü: Araştırma Makalesi

Bilgilendirme: Bu makale, 30 Ekim-01 Kasım 2018 tarihleri arasında Çanakkale'de düzenlenmiş olan 2. Uluslararası Sosyal Bilimler Eğitimi Sempozyumunda sözlü bildiri olarak sunulmuştur.

Kaynak Gösterimi: Yüksel Şahin, F., \& Taşkın, T. (2019). Çalışmayan ev kadınlarının mutluluk ve kişisel gelişim yönelimi düzeylerinin incelenmesi. Eğitimde Kuram ve Uygulama, 15(Özel Sayı 1), 24-36. doi: 10.17244/eku.491068

\section{Examination of The Levels of Happiness and Self-Improvement Tendencies Among Unemployed Housewives}

\author{
Fulya YÜKSEL ŞAHIN ${ }^{1}$, Tülay TAŞKIN ${ }^{2}$ \\ ${ }^{1}$ Department of Educational Sciences, Faculty of Education, Yıldız Teknik University, Istanbul, Turkey \\ ${ }^{2}$ Department of Educational Sciences, Graduate School of Social Sciences, Yıldız Teknik University, Istanbul, Turkey
}

Corresponding Author: Fulya YÜKSEL ŞAHIN, fusahin@yildiz.edu.tr

Article Type: Research Article

Acknowledgement: This article was orally presented as a paper at the 2nd International Symposium on Social Sciences Education organized between 30th October and 1st November in Çanakkale, Turkey.

To Cite This Article: Yüksel Şahin, F., \& Taşkın, T. (2019). Çalışmayan ev kadınlarının mutluluk ve kişisel gelişim yönelimi düzeylerinin incelenmesi. Eğitimde Kuram ve Uygulama, 15(Özel Sayı 1), 24-36. doi: 10.17244/eku.491068 
2019, 15(Özel Sayı 1), 24-36

\title{
Çalışmayan Ev Kadınlarının Mutluluk ve Kişisel Gelişim Yönelimi Düzeylerinin İncelenmesi
}

\author{
Fulya YÜKSEL ŞAHIN ${ }^{1}$, Tülay TAŞKIN ${ }^{2}$ \\ ${ }^{l}$ Eğitim Bilimleri Bölümü, Eğitim Fakültesi, Yıldız Teknik Üniversitesi, Ístanbul, Türkiye \\ ORCID: https://orcid.org/0000-0003-3454-2142 \\ ${ }^{2}$ Eğitim Bilimleri Anabilim Dal, Sosyal Bilimler Enstitüsü, Yıldız Teknik Üniversitesi, İstanbul, Türkiye \\ ORCID: https://orcid.org/0000-0001-5228-8008
}

\begin{tabular}{|c|c|}
\hline Öz & Makale Bilgisi \\
\hline 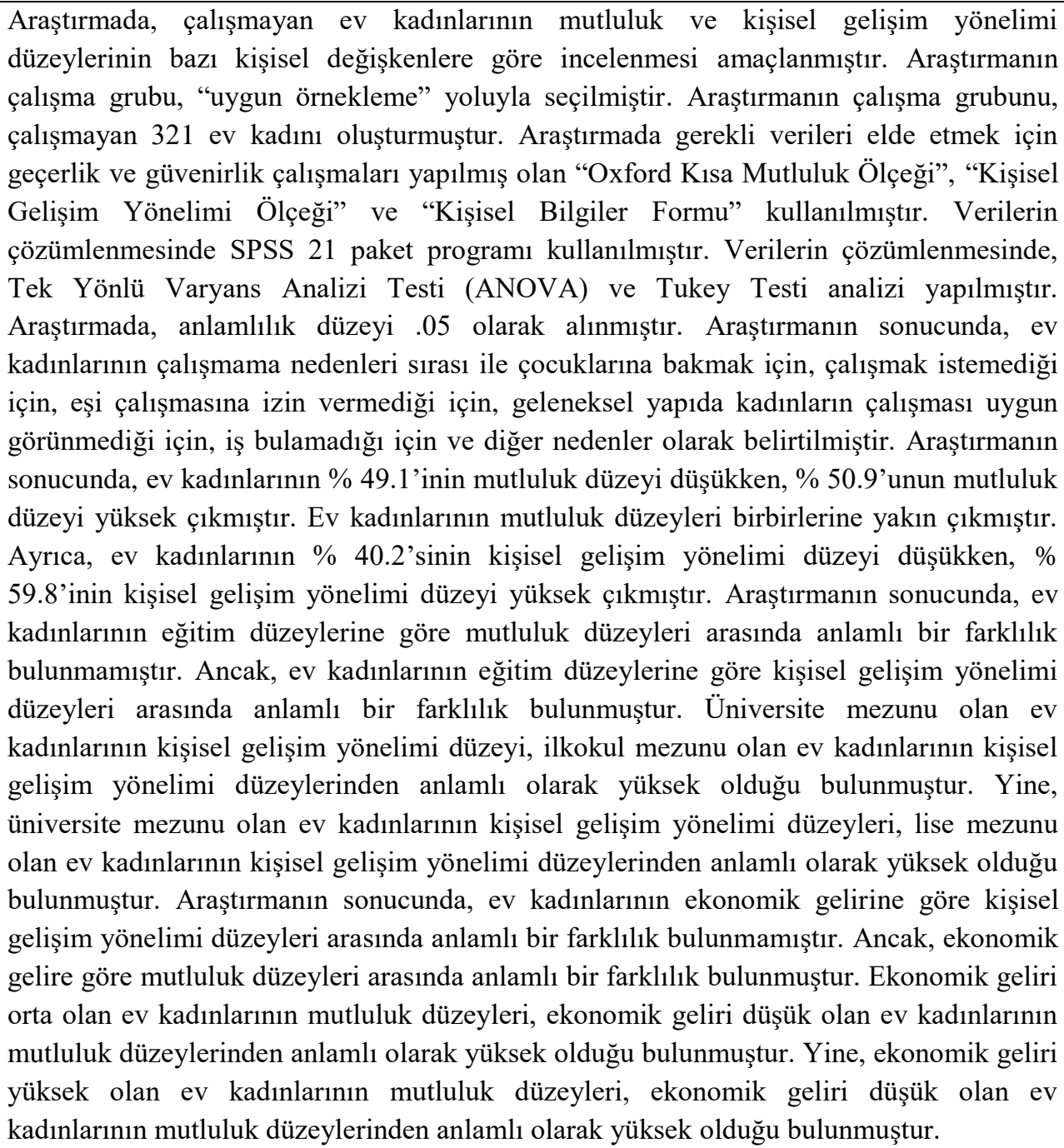 & $\begin{array}{l}\text { Makale Geçmişi: } \\
\text { Geliş: } 01 \text { Aralık } 2018 \\
\text { Düzeltme: 01 Ocak } 2019 \\
\text { Kabul: } 11 \text { Mart } 2019\end{array}$ \\
\hline
\end{tabular}

İletişim/Contact: fusahin@yildiz.edu.tr

DOI: $\underline{\text { https://doi.org/10.17244/eku.491068 }}$ 


\section{Examination of The Levels of Happiness and Self-Improvement Tendencies Among Unemployed Housewives}

\begin{abstract}
This is a descriptive study aiming to examine whether the levels of happiness and selfimprovement tendencies of unemployed housewives significantly differ according to certain personal variables. Selected using "convenient sampling", the study group consists of 321 housewives who were unemployed. The data was collected using the "Oxford Happiness Inventory" (short version), "Self-Improvement Tendency Scale", and a "Personal Information Form", for which all validity and reliability studies have been performed. SPSS 21 software pack was used for data analysis, for which One-Way Analysis of Variance (ANOVA), and Tukey Test were performed with a significance level of .05. According to the study results, the following reasons were identified for unemployment among housewives: for looking after kids, due to reluctance to work, because of the husband's unwillingness to allow his wife to work, since working is not deemed proper for women in traditional mentality, due to lack of jobs, and other reasons. The results revealed that $49.1 \%$ of the housewives have low levels of happiness, while $50.9 \%$ have high happiness levels, meaning that the housewives have similar levels of happiness. On the other hand, $40.2 \%$ of the housewives have low levels of selfimprovement tendencies, while the levels are high for $59.8 \%$. No significant difference was detected between the housewives' happiness levels according to their education levels. Yet, their levels of self-improvement tendencies significantly differ with their education levels. The housewives who graduated from a university have significantly higher levels of self-improvement tendencies than the primary school graduates. University graduates were also found to have significantly higher levels of selfimprovement tendencies when compared to the housewives who graduated from high schools. No significant difference was detected between the housewives' selfimprovement tendencies levels according to their economic income. Yet, their levels of the happiness significantly differ with their economic income. Housewives with a medium level of economic income were found to have significantly higher happiness levels than the housewives with low levels of economic income. Similarly, housewives with high economic income are significantly happier than those with low income levels.
\end{abstract}

Article Info

Keywords: Employment, Housewife, Happiness, SelfActualization, Self-

Improvement Tendency.

Article History:

Received: 01 December 2018

Revised: 01 January 2019

Accepted: 11 March 2019

Article Type: Research Article 
"İnsan topluluğu kadın ve erkek denilen iki cins insandan mürekkeptir. Kabil midir ki, bu kütlenin bir parçasını ilerletelim, ötekini ihmal edelim de kütlenin bütünlüğü ilerleyebilsin? Mümkün müdür ki, bir cismin yarısı topră̆a zincirlerle bağlı kaldıkça öteki kısmı göklere yükselebilsin?"

Mustafa Kemal ATATÜRK

\section{Giriş}

Kişisel gelişim, geçmişten günümüze üzerinde durulan bir konu olarak dikkati çekmektedir. Kişisel gelişim, insanın kendisini duygusal, sosyal ve davranışsal olarak en iyi bir biçimde yetiştirme ve var olan potansiyelini üst düzeyde ortaya koyması süreci olarak tanımlanmaktadır (Aksoy, Aytar, \& Kantez, 2017). Yetişkin benliğine sahip birey olma yolunda bireyin sahip olduğu potansiyelini, yeteneklerini ve kaynaklarını etkili biçimde kullanarak yaşam boyu gelişimini sürdürmesidir (Balaban \& Çakmak, 2016). Kişisel gelişim ile yakından ilişkili olan kendini gerçekleştirme ise bireyin tüm kapasitelerini kullanabilmesine (Amparado, 2014; Frager \& Fadiman,1984; Özaslan, 2018), gizli yeteneklerini geliştirmesine yönelik doğumdan itibaren var olan ve her bireyde bulunan insan ihtiyacı eğilimidir (Aluş, 2016). Bireyin sürekli olarak ulaşmaya çalıştı̆̆ bir amaçtır (Ciccarelli \& White, 2015), kendisini güdüleyen çok önemli bir güçtür ve devam eden bir süreçtir. Maslow'un ihtiyaçlar hiyerarşisinde kendini gerçekleştirme, en üst basamakta yer alır (Liebert \& Spiegler, 1990; Renner \& Feldman, 2013). Kendini gerçekleştirme, insanın kendi yeteneklerini tamamen kullanarak, hayalini kurduğu yere gelip, hedeflerine ulaşabilme isteği ve çabasıdır (Kaya, 2017). Birey, kendi yeteneklerini tam olarak kullanamazsa, hüsrana uğrar. Maslow, kendini gerçekleştiren kişilerin, ruh sağlığı yerinde ve kişisel gelişimlerine bağlı bireyler olduklarını belirtmektedir. Birey, daha iyi olmayı hedeflediğinde, kendini geliştirme ve güçlendirme güdüsü ortaya çıar. Kendini ve benliğini güçlendirme, bireyin kendisi hakkındaki olumlu duyguları ortaya çıkartır (Weiten, Hammer \& Dunn, 2016). Birey, kendi yeteneklerini tamamen kullanarak, hayalini kurduğu yere gelip, hedeflerine ulaşabilirse mutlu olur. Mutlu olan kişilerin olumlu duygulanımları fazla, olumsuz duygulanımları az; ve yaşam doyumları yüksek olur (Aksoy, Aytar \& Kantez, 2017; Diener, 1984; Eryılmaz, 2010). Yaşam doyumu, kişinin yaşamı hakkında yaptığı bilişsel değerlendirmedir (Diener, 1984). Olumlu duygulanım ümit, şefkat, gurur, güven, keyif, sevinç, ilgi, gibi duyguları içerirken; olumsuz duygulanım ise nefret, üzüntü, öfke, kızgınlık, suçluluk, kaygı gibi duyguları içerir (Diener, 1994). Yaşam doyumu insanların sahip olmak istedikleri durumla, sahip oldukları durumun karşılaştırılması ile elde edilen sonuçtur (Şahin, 2008). Yaşam doyumu tek yönlü, yaşamın yalnızca belirli bir bölümüne yönelik doyum sağlamayı ifade etmez. Yaşamın geneline yönelik olan mutluluk ve iyi olma halini ifade eder (Taş, 2011). Yaşam doyumu kişinin, boş zamanı, iş dışı zamanı ve işi olarak tanımlanan yaşamına yönelik gösterdiği duygusal tepkileridir (Dikmen, 1995).

Birey, iş dışı yaşamında ve iş yaşamında amaçlarına ulaşırsa yaşam doyumu yüksek olur ve mutlu olur. $\mathrm{Bu}$ bütünlük içinde bakıldığında, bireyin mutlu olmasını sağlayan önemli etmenlerden birisi de kariyer sahibi olması ve çalışma yaşamının içinde bulunmasıdır. Birey çalışarak, sahip olduğu bilgisini, becerisini ve yeteneklerini üretken bir yapıya dönüştürür. Çalışma yaşamı, bireylerin bedensel ve zihinsel etkinliklerini gerçekleştirdikleri (Özaydın \& Özdemir, 2014); ekonomik, sosyal, kültürel ve psikolojik açıdan doyum sağladıkları ortamlardır (Turan, 2018). Kadın, erkek ayrımı olmaksızın insanın kendi yeteneklerini kullanması, çalışması ve üretken olması çok önemlidir. Ancak, günümüzde hala kadınlara eğitim alma ve çalışma konusunda eşit olanaklar sunulmamaktadır. Cumhuriyetimizin ilanından sonra gerçekleştirilen devrimler içerisinde, Türk kadınına önemli sosyal haklar sağlanmıştır. Seçilme ve seçme hakkı, yasa önünde erkekle eşit konumda olma gibi temel hakların yanı sıra, 1936 İş Kanunu ile çalışma yaşamında da çeşitli düzenlemeler yapılmıştır. Türkiye'de 1950 yılından itibaren sanayileşme süreci geliştikçe, çalışan kadınların sayısı da artmıştır (Kırkpınar, 1998; Akt: Kuzgun \& Sevim, 2004). 1950'li yıllarda çalışan kadın oranı \% 70’lerde iken, 2000'li yıllarda \% 20'lere gerilemiştir (Zeren \& Kılınç-Savrul, 2017). Ülkemizde, kadınların en çok çalıştığı meslekler ise sırasıyla; temizlik görevlisi, satış danışmanı, muhasebeci, dikiş/makineci ve sekreter olarak belirtilmektedir (İşgücü Piyasası Araştırma Raporu, 2015).

Günümüzde, kadınların eğitimi ve çalışmasıyla ilgili gelişmeler istenilen düzeyde değildir (Kuzgun \& Sevim, 2004). Ne yazık ki; kızların büyük bir kısmı erken yaşta evliliğe ve çocuk sahibi olmaya zorlanmaktadırlar. Bu durum kadının güçlenmesini engellemektedir (Küçük, 2015). Kadının çalışma yaşamına katılımını olumsuz etkileyen faktörler olarak yaş, eğitim, medeni durum, kültürel faktörler, din ve sosyal normların olduğu belirtilmektedir (Kuzgun \& Sevim, 2004; Tatlı \& Koç, 2017). Ayrıca, kadınların özellikle düşük ücretli sektörlerde istihdam olanağı bulması da kadının çalışma isteğini kırmaktadır. Öte yandan çocuğun kreş ya da okul saatleri ile kadının çalışma saatlerinin uyumsuzluğu; yaşıı bakımı gibi konuların sorumluluğunun hâlâ kadınların omuzlarında yer alması, kadını çalışma yaşamından uzaklaştırmaktadır (Işık-Erol, 2015). Kadınlar, yalnızca öz bakımlarını yapamayan çocuk, yaşlı ve hastaların değil; aynı zamanda kendi bakımını yapabilecek durumda olan eşlerinin de bakım ihtiyacını karş1lamaktadırlar (Bhasin, 2003; Korkmaz \& Korkut, 2012; Sharf, 2014). 
Kadınların öncelikli sorumluluklarının ailesi ve evi olarak görüldüğ̈̈ ataerkil yapıya sahip olan ülkemizde kadının çalışma yaşamı, eğitim seviyesine göre değişiklik göstermektedir. Eğitim seviyesi yüksek kadınlar, statüsü yüksek olan örneğin, akademisyenlik gibi işleri yapabilmektedirler (Ergöl, Koç, Eroğlu \& Taşkın, 2012). Öte yandan, çalışan kadınların işleri çoğunlukla, aile içindeki işlerinin bir uzantısı gibi de olabilmektedir. Örneğin; kadınlar hemşirelik, ana okul öğretmenliği ya da havayolları hostesliği yapmaktadırlar (Bhasin, 2003). Üst düzey yöneticilik yapan kadın sayısı ise azdır. Çünkü, kadınların bir kurumda çalışırken üst düzeydeki yöneticilik görevlerini yerine getiremeyeceklerine yönelik kalıp yargılar vardır. Bu kalıp yargıları kabul eden kadınlar, kendi olanaklarını ve yeteneklerini keşfetmek için çaba göstermemektedirler (Gladding, 2013).

Çalışan kadınların kariyerleri kesintiye de uğramaktadır. Kadınlar, çocuk yetiştirme ve ailevi kriz durumları nedenleri ile çalışmaya ara verirler (Weiten, Hammer \& Dunn, 2016). Çalışmayan kadınların sosyal güvencesi yoktur. Geçinmek için de eşlerine bağımlıdırlar. Ev içinde yaptıkları işlerin ise maddi bir karşılığı yoktur (Güçray, 2009). Bu durum, kadınlarda mutsuzluk yaratmaktadır.

Ülkemizde 'kadınlık' kavramına denk görülen özellikler, kadının özgün, eşit ve bağımsız bir birey olması değildir. Dişiliği temsil ettiği düşünülen kadına, öncelikle ailenin bir üyesi, eş ve anne olma gibi özellikler yakıştırılmaktadır. Kadının yerinin, "evin içi” olduğu düşünülmektedir. Ev kadını ideolojisi, kadının eğitim almasını, çalışmasını, para kazanmasını ve sosyal yaşamın içinde bulunmasını birinci dereceden olumsuz etkilemektedir (Bingöl, 2014). "Evin reisi erkektir. Kadın ise evinde oturur, ev işleriyle uğraşır ve çocuğuna bakar," gibi "irrasyonel düşüncelerden" kaynaklanan tutumlar, kadının çalışmasını engellemektedir. Bu şekilde tanımlanan roller de aile sisteminde hiyerarşik bir yapı oluştururlar. Kadınlara, eş ve çocuklarla ilgilenme sorumluluğunu verirler. Erkeklere ise çalışarak evin geçimini sağlama sorumluluğunu verirler (Çelik, 2008; Göksel Oflas, 2016). Bu roller, toplumsal cinsiyet kalıp yargılarıdır. Bu kalıp yargıları doğal değil, kültürel ve toplumsal niteliktedirler. Kadınlarla erkekler arasında belirgin farklılıklar oluştururlar. Kadın ve erkeğin iş, meslek tercihlerini etkilerler (Bhasin, 2003).

Yukarıda sayılan nedenlerden dolayı birçok kadın, çalışma yaşamının dışında kalmaktadır. Oysa, çalışma yaşamı kadınların kendilerine olan güvenlerini artıır, onları özgürleştirir, kendi kararlarını almak ve söylemek konusunda cesaretlerini artırır (Alp, 2007). Onlara, toplumsal saygınlık kazandırır. Kadına ekonomik özgürlük sağlar ve aile içindeki konumlarını da iyileştirir (Korkmaz \& Korkut, 2012). Ruhsal, fiziksel, sosyal, duygusal sağlık ve ilişkiler açısından yarar sağlar (Taylor, Peplau, \& Sears, 2012; Weiten, Hammer, \& Dunn, 2016). Bu durum kadınların kişisel gelişimine, kendini gerçekleştirmesine ve mutlu olmasına katkı sağlar.

Yapılmış olan araştırmalarda, çalışmayan kadınlarda psikolojik stresin ve depresif belirtilerin daha çok olduğu belirtilmektedir. Bir işte çalışmanın ruh sağlığını koruyucu bir etkisi vardır (Dökmen, 2003, 2009). Kadınların ücretli bir işte çalışmaları, duygusal durumları üzerinde pozitif bir etki yapmaktadır (Çilli et al., 2004). Yüksek gelirli ülkelerde yapılan çalışmalar, kadınların çalışma yaşamına katılımıyla yaşam beklentisinin arttı̆̆ını, mortalitenin azaldığını, mental ve fizik sağlığın daha iyi düzeye çıktığını göstermektedir. Bireyin bir işte çalışması, kişinin kendini var etmesini sağlar; yeteneklerini ve becerilerini kullanarak yaşam doyumunu sağlar (Türkdoğan \& Duru, 2012). Mutluluk düzeyini arttırır (Taylor, Peplau, \& Sears, 2012).

Kadınların işgücüne olan katılımını inceleyen araştırmalar (Örneğin; İşgücü Piyasası Araştırma Raporu, 2015; Kuzgun \& Sevim, 2004; Tatlı \& Koç, 2017; TÜiK, 2016; Zeren \& Kılınç-Savrul, 2017) vardır. Bu araştırmaların birçoğunda, ekonomik boyut, ülkelerin kalkınması gibi iktisadi konular ele alınmaktadır. Çalışmayan ev kadınları ile ilgili araştırmalar (Örneğin; Çilli et al., 2004; Kuzgun \& Sevim, 2004; Kholasezadeh,Vaseghi, Ahmadi, \& Abedinzadeh, 2012; Yıldırım \& Işık, 2017) ise yok denecek kadar azdır. Çalışmayan ev kadınlarının psikolojik durumlarını inceleyen araştırmaların çok az olması, bu araştırmanın ortaya çıkmasına 1şık tutmuştur. Bu araştırmanın amacı, kadınların çalışmama nedenlerini; mutluluk ve kişisel gelişim yönelimi düzeylerini incelemektir. Ayrıca, araştırmada çalışmayan ev kadınlarının mutluluk ve kişisel gelişim yönelimi düzeylerinin eğitim düzeyine ve ekonomik gelire göre incelenmesi de amaçlanmıştır.

\section{Yöntem}

$\mathrm{Bu}$ araştırma, çalışmayan ev kadınlarının mutluluk ve kişisel gelişim yönelimi düzeylerinin, bazı kişisel değişkenlere göre incelenmesini amaçlayan betimsel ve nedensel karşılaştırma araştırmasıdır. Araştırmanın bir amacı betimlemek, diğer amacı da nedensel ilişkileri bulmaktır (Balc1, 2010). 


\section{Çalışma Grubu}

$\mathrm{Bu}$ araştırmanın çalışma grubu, "uygun örnekleme" yoluyla seçilmiştir. Uygun örnekleme, araştırmacının kolayca ulaşabileceği bir örneklemden verileri elde etmesi ile yapılmaktadır (Büyüköztürk et. al., 2015). Araştırmanın çalışma grubunu, çalışmayan 321 ev kadını oluşturmuştur. Ev kadınları, araştırmaya gönüllü olarak katılmıştır.

\section{Veri Toplama Araçları}

Bu araştırmada, veri toplama aracı olarak "Oxford Kısa Mutluluğu Ölçeği”, "Kişisel Gelişim Yönelimi Ölçeği” ve "Kişisel Bilgiler Formu" kullanılmıştır. Bu ölçekler sırası ile aşağıda açıklanmıştır.

\section{Oxford Kısa Mutluluk Ölçeği (OMO-K)}

Araştırmada, "Oxford Kısa Mutluluk Ölçeğì" kullanılmıştır. Ölçek, bireylerin mutluluk düzeyini değerlendirebilmek amacıyla Hills ve Argyle tarafindan 2002 yılında geliştirilmiş; ülkemize uyarlama çalışması ise Doğan \& Akınc1Çötok (2011) tarafından yapılmıştır. Ölçek, 5'li Likert tipi, 7 maddelik bir ölçektir. OMÖ-K'nın yapı geçerliğini belirlemek amacıyla Açımlayıcı Faktör Analizi (AFA) ve Doğrulayıcı Faktör Analizi (DFA) yapılmıştır. AFA sonucu özdeğeri 2.782 olan ve toplam varyansın \% 39.74'ünü açıklayan tek faktörlü bir yapı bulunmuştur. Doğrulayıcı Faktör Analizi (DFA) sonucunda, ki kare değerinin serbestlik derecesine oranı, 35.05/13 2.77 olarak bulunmuştur. Modelin iyi düzeyde uyum gösterdiği bulunmuştur.

Ölçeğin, benzer ölçekler geçerliğine de bakılmıştır. OMÖ-K ile Yaşam Yönelimi Testi (YYT) arasında ise anlamlı ve pozitif yönde bir ilişki $(.51, p<.001)$; OMÖ-K ile Zung Depresyon Ölçeği (ZDÖ) arasında anlamlı ve negatif bir ilişki $(.48, p<.001)$; ve OMÖ-K ile Yaşam Doyumu Ölçeği (YDÖ) arasında anlamlı ve pozitif bir ilişki $(.61, p<.001)$ bulunmuştur. Ölçeğin Cronbach Alfa iç tutarlılık değeri .74; ve test tekrar test güvenirlik değeri ise .85 olarak bulunmuştur. Bu bulgular ölçeğin, geçerli ve güvenilir bir ölçme aracı olduğunu göstermektedir.

\section{Kişisel Gelişim Yönelimi Ölçeği (KGYÖ-II)}

Ölçek, bireyin kişisel gelişim düzeyini ölçmek amacıyla, Robitschek ve arkadaşları tarafından 1998 yılında geliştirilmiştir. Ölçeğin uyarlama çalışması, Yalçın \& Malkoç (2013) tarafından yapılmıştır. Ölçek, 16 maddelik, 6'lı Likert tipi bir ölçektir. Ölçeğin yapılan Doğrulayıcı Faktör Analizi (DAF) sonucunda, ölçeğin 4 alt boyutu (değişime hazır olma, kaynakları kullanma, planlı olma, amaçlı davranış) olduğunu ortaya konmuştur. 4 faktör için 98 serbestlik derecesinde elde edilen ki kare $(\chi 2)$ değeri 220.49 'dur $(\chi 2 / \mathrm{SS}=2.25)$. Uyum indeks değerleri RMSEA $=.067, \mathrm{CFI}=.98$, $\mathrm{NFI}=.97, \mathrm{SRMR}=.14, \mathrm{IFI}=.98, \mathrm{RFI}=.96$ şeklinde bulunmuştur. Alt ölçekler arasındaki korelasyonlar ise .83 ile .18 arasında değişmektedir. Ölçeğin güvenilirliği, test-tekrar test yöntemleriyle ve iç tutarlık katsayısı ile incelenmiştir. Zaman aralıkları (1, 2, 4 ve 6 hafta) içerisinde yapılan test-tekrar test güvenilirlik çalışmaları sonucunda, güvenilirlik değerlerinin .62 ile .82 arasında değiştiği görülmüştür. Tüm ölçek için .80'dir. Ölçeğin alt boyutlarının Cronbach Alfa iç tutarlılık katsayıları .81 ile .89 arasında değişmektedir. Tüm ölçek için Cronbach Alfa katsayısı ise .91 'dir. Bu bulgular ölçeğin, geçerli ve güvenilir bir ölçme aracı olduğunu göstermektedir.

\section{Kişisel Bilgi Formu}

Kişisel Bilgi Formu, araştırmacılar tarafından geliştirilmiştir. Formda, katılımcıların çalışmama nedenleri, eğitim düzeyleri ve ekonomik gelirlerine yönelik sorular bulunmaktadır. Formun başında araştırmanın amacına yer verilmiş olup değerlendirmenin bireysel şekilde değil toplu yapılacağı açıklanarak ölçeklere isim yazılmaması belirtilmiştir.

\section{İşlem Yolu}

Ölçekler, özenle çalışma grubuna uygulanmıştır. Tam olarak doldurulmuş olan ölçekler değerlendirilmeye alınmıştır. 2018 yılında 321 çalışmayan ev kadınına ölçekler uygulanmıştır. Katılımcıların verecekleri cevapların doğru ve içten olması için gerekli açıklamalar yapılarak katılımcılar bilgilendirilmiştir.

\section{Verilerin Analizi}

Verilerin elde edilebilmesi için ölçekler çalışmayan ev kadınlarına uygulanmıştır. Verilerin çözümlenmesinde SPSS 21 paket programı kullanılmıştır. Öncelikle, “Oxford Kısa Mutluluk Ölçeği (OMO-K)”nden ve "Kişisel Gelişim Yönelimi Ölçeği”nden elde edilen puanların normal dağılım gösterip göstermediğini belirlemek için alınan puanların çarpıklık katsayıları (Skewness) ve basıklık (Kurtosis) katsayılarının hesaplaması yapılmıştır. Verilerin çözümlenmesinde, Tek Yönlü Varyans Analizi Testi (ANOVA) ve Tukey Testi analizi yapılmıştır. Ayrıca, ev kadınlarının çalışmama nedenlerinin, mutluluk ve kişisel gelişim yöneliminin yüzdelik değerleri de hesaplanmıştır. Araştırmada, anlamlılık düzeyi .05 olarak alınmıştır. 


\section{Bulgular}

$\mathrm{Bu}$ bölümde, araştırmada ele alınan problemin çözümü için toplanan verilerin istatistiksel çözümlenmesi sonucunda elde edilen bulgulara iliş̧in ulaşılan sonuçlara yer verilmiş̧ir.

Problemin çözümü için öncelikle "Oxford Kısa Mutluluk Ölçeği (OMO-K)"nden ve "Kişisel Gelişim Yönelimi Ölçeği”nden elde edilen puanların normal dağılım gösterip göstermediğini belirlemek için alınan puanların çarpıklık katsayılarına (Skewness) ve basıklık (Kurtosis) katsayılarına bakılmıştır. Mutluluk Ölçeğinin toplam puanların çarpıklık katsayılarının (Skewness) için .39; basıklık (Kurtosis) için 1.56 olduğu; Kişisel Gelişim Yönelimi Ölçeğinin toplam puanların çarpıklık katsayılarının (Skewness) için .94; basıklık (Kurtosis) için .44 olduğu; yani normalden sapmadıkları görülmektedir. Herhangi bir veri grubunda basıklık ve çarpıklık değerinin $-2,+2$ aralığında olması da kabul edilebilir bir durumdur (Cooper Cutting, 2010; as cited in: Arapkirlioğlu \& Tankız, 2011).

Araştırmada, ev kadınlarının çalışmama nedenlerinin yüzdelikleri hesaplanmış ve Tablo 1'de verilmiştir.

Tablo 1. Ev kadınlarının çalışmama nedenlerinin yüzdelik değerleri

\begin{tabular}{lcc}
\hline Çalışmama Nedenleri & n & \% \\
\hline Kendim çalışmak istemedim & 78 & 24.1 \\
Eşim izin vermedi & 74 & 22.9 \\
Çocuklarıma bakmak için çalışmak istemedim & 151 & 46.7 \\
Geleneksel yapımızda kadınların çalışması uygun görülmez & 19 & 5.9 \\
İş bulamadım & 18 & 5.6 \\
Diğer Nedenler & 25 & 7.7 \\
\hline
\end{tabular}

Tablo 1'de görüldüğü gibi, ev kadınlarının çalışmama nedenleri sırası ile \% 46.7'si (n=151) çocuklarına bakmak için; \% 24.1'i (n=78) çalışmak istemediği için; \% 22.9'u (n=74) eşi çalışmasına izin vermediği için; \% 5.9'u $(\mathrm{n}=19)$ geleneksel yapıda kadınların çalışması uygun görülmediği için; \% 5.6'sı $(\mathrm{n}=18)$ iş bulamadığı için ve \% 7.7'si $(n=25)$ diğer nedenler olarak belirtilmiştir (Not: Soruyu cevaplayan katılımcılar, birden fazla seçeneği işaretleyebildikleri için toplam yüzdelik sayısı fazla çıkmaktadır).

Araştırmada, ev kadınlarının mutluluk ve kişisel gelişim yönelimi düzeyleri puan ortalamaları ve yüzdelikleri hesaplanmış ve Tablo 2'de verilmiştir.

Tablo 2. Ev kadınlarının mutluluk ve kişisel gelişim yönelimi puan ortalamaları ve yüzdelik değerleri

\begin{tabular}{|c|c|c|c|c|c|c|c|}
\hline \multirow[t]{2}{*}{ Değişkenler } & \multirow[t]{2}{*}{$n$} & \multirow{2}{*}{$\begin{array}{l}\text { En Düşük } \\
\text { Puan }\end{array}$} & \multirow{2}{*}{$\begin{array}{c}\text { En } \\
\text { Yüksek } \\
\text { Puan }\end{array}$} & \multirow[t]{2}{*}{$\overline{\mathrm{X}}$} & \multirow[t]{2}{*}{ Ss } & \multicolumn{2}{|c|}{$\%$} \\
\hline & & & & & & Düşük & Yüksek \\
\hline Mutluluk & 321 & 8 & 48 & 24.36 & 5.23 & 49.1 & 50.9 \\
\hline $\begin{array}{l}\text { Kişisel Gelişim } \\
\text { Yönelimi }\end{array}$ & 321 & 4 & 79 & 51.23 & 16.38 & 40.2 & 59.8 \\
\hline
\end{tabular}

Tablo 2'de görüldüğ̈̈ gibi, ev kadınlarının mutluluk toplam puan ortalaması $\overline{\mathrm{X}}=24.36$, Ss $=5.23$; ve kişisel gelişim yönelimi toplam puan ortalaması $\overline{\mathrm{X}}=51.23$, Ss=16.38'dir. Yine, Tablo 2'de görüldüğü gibi, ev kadınlarının \% 49.1'inin mutluluk düzeyi düşükken, \% 50.9'unun mutluluk düzeyi yüksek çıkmıştır. Ayrıca, ev kadınlarının \% 40.2'sinin kişisel gelişim yönelimi düzeyi düşükken, \% 59.8'inin kişisel gelişim yönelimi düzeyi yüksek çıkmıştır.

Araştırmada, ev kadınlarının mutluluk ve kişisel gelişim yönelimi puanlarının eğitim düzeyine göre anlamlı olarak farklılık gösterip göstermediğine yönelik Tek Yönlü Varyans Analizi Testi uygulanmış ve sonuç Tablo 3'de gösterilmiştir.

Tablo 3. Eğitim düzeyine göre mutluluk ve kişisel gelişim yöneliminin tek yönlü varyans analizi testi sonuçları

\begin{tabular}{lccccc}
\hline Kaynak & $\begin{array}{c}\text { Kareler } \\
\text { Toplamı }\end{array}$ & Sd & $\begin{array}{c}\text { Kareler } \\
\text { Ortalaması }\end{array}$ & F & P \\
\hline Mutluluk & 193.865 & 6 & 32.311 & 1.08 & .37 \\
$\begin{array}{l}\text { Gruplar Arası } \\
\text { Gruplar İçi }\end{array}$ & 9394.771 & 314 & 29.920 & & \\
Toplam & 9588.636 & 320 & & & \\
\hline Kişisel Gelişim Yönelimi & & & & \\
Gruplar Arası & 4389.829 & 6 & 731.638 & 2.74 & \\
Gruplar İçi & 83769.224 & 314 & 266.781 & & \\
Toplam & 88159.053 & 320 & & &
\end{tabular}


Tablo 3'de görüldüğü gibi, ev kadınlarının eğitim düzeylerine göre mutluluk puan ortalamaları arasında anlamlı bir farklılık bulunmamıştır $(F=1.08, p>$.05). Ayrıca Tablo 3'de görüldüğü gibi, ev kadınlarının eğitim düzeylerine göre kişisel gelişim yönelimi puan ortalamaları arasında anlamlı bir farklılık bulunmuştur $(F=2.74, p<$ .01). Bu farklılıkların hangi eğitim düzeyinde olduğunu belirleyebilmek için yapılan Tukey Testi sonuçları Tablo 4'de verilmiştir.

Tablo 4. Eğitim düzeyine göre kişisel gelişim yönelimi düzeyi için Tukey testi sonuçları

\begin{tabular}{llllllllllll}
\hline Ĕgitim Düzeyi & & $\mathbf{n}$ & $\mathbf{X}$ & $\mathbf{( 1 )}$ & $\mathbf{( 2 )}$ & $\mathbf{( 3 )}$ & $\mathbf{( 4 )}$ & $\mathbf{( 5 )}$ & (6) & (7) & (8) \\
\hline Okuryazar Değil & $(1)$ & 5 & 43.60 & & & & & & & & \\
Okuryazar & $(2)$ & 10 & 49.90 & & & & & & & \\
İlkokul & $(3)$ & 112 & 49.37 & & & & & & $9.98^{*}$ & & \\
Ortaokul & $(4)$ & 45 & 50.73 & & & & & & & & \\
Lise & $(5)$ & 99 & 49.92 & & & & & & $9.44^{*}$ & & \\
Üniversite & $(6)$ & 48 & 59.35 & & & & & & & & \\
Yüksek Lisans & $(7)$ & 2 & 38 & & & & & & & & \\
Doktora & $(8)$ & 0 & 00 & & & & & & & & \\
\hline
\end{tabular}

Tablo 4'de görüldüğü gibi, üniversite mezunu olan ev kadınlarının kişisel gelişim yönelimi puan ortalamasının ( $\bar{X}=59.35$ ), ilkokul mezunu olan ev kadınlarının kişisel gelişim yönelimi puan ortalamasından ( $\bar{X}=49.37)$ anlamlı düzeyde $(\mathrm{p}<.00)$ yüksek olduğu bulunmuştur. Yine, üniversite mezunu olan ev kadınlarının kişisel gelişim yönelimi puan ortalamasının ( $\bar{X}=59.35$ ), lise mezunu olan ev kadınlarının kişisel gelişim yönelimi puan ortalamasından ( $\overline{\mathrm{X}}=49.92$ ) anlamlı düzeyde $(\mathrm{p}<.02)$ yüksek olduğu bulunmuştur.

Araştırmada, ev kadınlarının mutluluk ve kişisel gelişim yönelimi puanlarının, ekonomik gelire göre anlamlı olarak farklılık gösterip göstermediğine yönelik Tek Yönlü Varyans Analizi Testi uygulanmış ve sonuç Tablo 5'de gösterilmiştir.

Tablo 5. Ekonomik gelire göre mutluluk ve kişisel gelişim yöneliminin tek yönlü varyans analizi testi sonuçları

\begin{tabular}{lccccc}
\hline Kaynak & $\begin{array}{c}\text { Kareler } \\
\text { Toplamı }\end{array}$ & Sd & $\begin{array}{c}\text { Kareler } \\
\text { Ortalaması }\end{array}$ & F & P \\
\hline Mutluluk & 205.139 & 2 & 102.570 & 3.48 & .03 \\
$\begin{array}{l}\text { Gruplar Arası } \\
\text { Gruplar İçi }\end{array}$ & 9383.496 & 318 & 29.528 & & \\
Toplam & 9588.636 & 320 & & & \\
\hline Kişisel Gelişim Yönelimi & & & & & \\
Gruplar Arası & 618.583 & 2 & 309.292 & 1.12 & .33 \\
$\begin{array}{l}\text { Gruplar İçi } \\
\text { Toplam }\end{array}$ & 87540.470 & 318 & 275.284 & & \\
\hline
\end{tabular}

Tablo 5'de görüldüğü gibi, ev kadınlarının ekonomik gelire göre kişisel gelişim yönelimi puan ortalamaları arasında anlamlı bir farklılık bulunmamıştır $(\mathrm{F}=1.12, \mathrm{p}>.05)$. Ancak, Tablo 5 'de görüldügü gibi, ev kadınlarının ekonomik gelire göre mutluluk puan ortalamaları arasında anlamlı bir farklılık bulunmuştur $(\mathrm{F}=3.48, \mathrm{p}<.03)$. $\mathrm{Bu}$ farklılıkların hangi gelir düzeyinde olduğunu belirleyebilmek için yapılan Tukey Testi sonuçları Tablo 6'da verilmiştir.

Tablo 6. Ekonomik gelire göre mutluluk düzeyi Tukey testi sonuçları

\begin{tabular}{llllllll}
\hline $\begin{array}{l}\text { Ekonomik } \\
\text { Gelir }\end{array}$ & & $\mathbf{n}$ & $\mathbf{X}$ & (1) & (2) & (3) & (4) \\
\hline Düsük & $(1)$ & 24 & 21.50 & & $2.83^{*}$ & $3.59^{*}$ & \\
Orta & $(2)$ & 265 & 24.33 & & & & \\
Yüksek & $(3)$ & 32 & 25.09 & & & & \\
Çok Yüksek & $(4)$ & 0 & 00 & & & & \\
& & & & & & & \\
\hline
\end{tabular}

Tablo 6'da görüldüğü gibi, ekonomik geliri orta olan ev kadınlarının mutluluk puan ortalamasının ( $\bar{X}=24.33$ ), ekonomik geliri düşük olan ev kadınlarının mutluluk puan ortalamasından ( $\bar{X}=21.50$ ) anlamlı düzeyde $(\mathrm{p}<.04)$ yüksek olduğu bulunmuştur. Yine, ekonomik geliri yüksek olan ev kadınlarının mutluluk puan ortalamasının ( $\bar{X}=25.09)$ ekonomik geliri düşük olan ev kadınlarının mutluluk puan ortalamasından $(\bar{X}=21.50)$ anlamlı düzeyde $(\mathrm{p}<.04)$ yüksek olduğu bulunmuştur. 


\section{Tartışma ve Yorum}

Araştırmamızın sonucunda, ev kadınlarının çalışmama nedenleri sırası ile çocuklarına bakmak için; çalışmak istemediği için, eşi çalışmasına izin vermediği için, geleneksel yapıda kadınların çalışması uygun görünmediği için, iş bulamadığı için ve diğer nedenler olarak belirtilmiştir. Ülkemizde, kadının yerinin, "evin içi” olduğu düşünülmektedir. $\mathrm{Ne}$ yazık ki, erkekler de eşlerinin ve kızlarının çalışmak için kamusal alana girme koşullarını belirleme durumundadırlar (Bhasin, 2013). Bu düşünceler, kadının eğitim almasını, çalışmasını, para kazanmasını ve sosyal hayatın içinde bulunmasını engellemektedir (Bingöl, 2014). Toplumsal cinsiyet rolleri olarak açıklanan bu kalıp yargılara göre kadınlara yüklenen geleneksel roller; ev işlerini yapma, zamanını evde geçirme, anne olma, iş hayatında pasif kalarak erkeklerle güç yarışına girmeme gibi eşitlikçi olmayan düşünceleri içermektedir. Erkeklere yüklenen geleneksel roller; evi geçindirme, evin reisi olma, güçlü olma gibi sorumluluklardır. Aslında olması gereken roller eşitlikçi rollerdir. Eşitlikçi roller; aile, evlilik, iş, eğitim ve sosyal hayatında erkek ve kadının sorumlulukları eşit şekilde paylaşmalarıdır (Bhasin, 2003; Göksel Oflas, 2016). Cinsiyete eşitlikçi tutumla yaklaşan bireylerin ihtiyaçlarına duyarlı oldukları (Nevill, 1977); psikolojik iyi oluş düzeylerinin daha yüksek olduğu (Kim, 1998) ve olumlu içsel yaşantılara sahip oldukları (Golding \& Singer, 1983) görülmektedir. Eşitlikçi tutuma sahip olan bireylerin, özgür şekilde davranabilmeleri, gereksinimlerini karşılayabilmeleri ve bunun için çalışma yaşamına katılmaları psikolojik yönden daha sağlıklı olmalarını sağlayacaktır. Ancak, bu şekilde kadınlar kişisel gelişim ve kendini gerçekleştirme yolunda ilerleyebilirler.

Türkiye'de yapılan araştırma sonuçlarından, kadınların işgücüne katılım oranları üzerinde kadının toplumsal cinsiyet algısının, eğitim durumunun, medeni durumunun ve çocuk sayısının çok etkili olduğu görülmektedir. Yine, Devlet Planlama Teşkilatı (DPT) ve Dünya Bankası (DB) tarafından 2009 yılında gerçekleştirilen araştırmanın sonucunda, Türkiye'de kadınların çalışma yaşamına girişte ve çalışma yaşamı süresinde önemli sorunlarla karşılaştıkları bulunmuştur. Araştırmanın sonucunda kadının çalışma yaşamına katılmasını mümkün kılacak, kadınların iş arama süreçlerinin kolaylaştırılması, eğitim düzeyinin arttırılması, çocuk bakımı olanaklarının sağlanması gibi önerilerde bulunulmuştur (Kılıç \& Öztürk, 2014). Türkiye İstatistik Kurumu (TÜİK) 2016 verilerine göre ülkemizde çalışan kadınların istihdam oranı \%28'dir. Görüldüğü gibi, Türkiye'de çalışan kadınlar, erkek çalışanlara göre sayıca daha azdır. Çalışan kadının ayrıca, ev işleri ve çocuk işleri ek olarak devam etmektedir. Mesleği ne olursa olsun kadın, aynı zamanda vazgeçilmez bir ev işçisi olarak düşünülmektedir. Erkek ise ev işleri ve çocuk işleri gibi sorumluluklardan muaf tutulmaktadır ya da kadına göre daha hafif düzeydedir. Oysa kadın ve erkeğin benzer eşitlikte olması gerekir (Bingöl, 2014). Kadınların çalışma yaşamında olmaları gerekir. Kadınların çalışarak işgücüne katılmaları ve üretken olmaları sosyal ve ekonomik yönden kalkınmayı sağlar. Yoksulluğu azaltır. Çalışarak ekonomik özgürlüklerinin yanı sıra kendine güveni ve toplumsal saygıyı kazanan kadınların hem kendileri hem aileleri hem de toplum için önemli birçok kazanımları sağlayacakları (Kılıç \& Öztürk, 2014), kişisel gelişimlerini ve mutluluklarını arttıracakları açıktır.

Araştırmamızın sonucunda, ev kadınlarının \% 49.1'inin mutluluk düzeyi düşükken, \% 50.9'unun mutluluk düzeyi yüksek çıkmıştır. Yapılmış olan bir araştırmada, ülkemizdeki kadınların \% 53'ü mutludur. Kadınların mutluluk kaynaklarının \% 65.9'u tüm aile, \% 19.3'ü çocuklar ve ancak \% 1.6'sı kendisi olduğu görülmektedir (Bingöl, 2014). Türkiye'de genellikle çocuğun bakımı ve ev işleri büyük oranda kadının üzerindedir. Kadının ev dışında ücretli çalışmaya başlamasıyla yükü daha da fazlalaşmaktadır. Gerek ev içinde gerekse iş yaşamında yoğun bir biçimde çalışan kadınlarda olumsuz psikolojik semptomların daha fazla olması beklenebilir. Oysa, yapılmış olan araştırmalarda, kadınların ücretli bir işte çalışmasının ruh sağlığını koruyucu bir etkisinin olduğu ve duygu durumları üzerinde de olumlu etkiler yaptığı bulunmuştur. Çalışan kadınların özellikle benlik saygılarının, yaşam doyumlarının ve genel sağlıklarının daha yüksek olduğu; kaygı, ümitsizlik ve güvensizliğin ise daha düşük olduğu gösterilmiştir (Çilli et al., 2004). Çalışmayan kadınlarda ise yaşam doyumunun daha düşük (Yıldırım \& Işık, 2017), psikolojik stresin ve depresif belirtilerin daha fazla olduğu görülmektedir (Çilli et al., 2004). "Ücretli bir işte çalışmayan" kadınların "çalışan ya da emekli" kadınlara göre daha yüksek olumsuz benlik, kaygı, somatizasyon, depresyon belirtileri gösterdikleri görülmektedir. Bir işte çalışmanın ruh sağlığını koruyucu bir etkisi vardır (Dökmen, 2003, 2009; Kholasezadeh,Vaseghi, Ahmadi, \& Abedinzadeh, 2012). 
Ayrıca araştırmamızın sonucunda, ev kadınlarının \% 40.2'sinin kişisel gelişim yönelimi düzeyi düşükken \% 59.8'inin kişisel gelişim yönelimi düzeyi yüksek çıkmıştır. Kendini Gerçekleştirme, bireyin kendi yeteneklerini sonuna kadar kullanarak istediği yere gelebilme ve amaçlarına ulaşabilme isteği ve çabası olarak tanımlanır (Bülbül \& Giray, 2011). Bireyin bir işte çalışmasının bir yönü kişinin kendini var etmesi, yeteneklerini ve becerilerini kullanarak yaşam doyumu sağlamasıdır. Yüksek gelirli ülkelerde yapılan çalışmalar, kadınların çalışma yaşamına katılımıyla yaşam beklentisinin arttığını, mortalitenin azaldığını, mental ve fizik sağlığın daha iyi düzeye çıktığını göstermektedir (Türkdoğan \& Duru, 2012). Araştırma bulgumuzla dolaylı ilgisi olan bir araştırmanın sonucunda, kendini gerçekleştirme ile sosyal görünüş anksiyetesi arasında olumsuz bir ilişki bulunmuştur. Ev kadınları sosyal görünüş anksiyetesi nedeniyle, kendilerini gerçekleştirebileceği girişimlerden ve ortamlardan uzak durabilirler. Diğer yandan, ev kadınlarının üstlendiği sosyal ve kültürel rol ve sorumluluklarından dolayı kendilerini gerçekleştirebilme yönünde firsatları oluşturmada geri planda kalabilirler. Ancak, ev kadınlarına kendilerini gerçekleştirebilme olanakları sağlandığında, sosyal görünüş anksiyetelerinin azalması ve sonuç olarak ruhsal sağlıklarının olumlu etkilenmesi mümkün olabilir (Ünal \& Şahin, 2013).

Araştırmamızın sonucunda, ev kadınlarının eğitim düzeylerine göre mutluluk düzeyleri arasında anlamlı bir farklı1ık bulunmamıştır. Frey-Bruno \& Stutzer'a (2002) göre eğitim düzeyi ile mutluluk arasında doğrudan bir ilişki yoktur (As cited in: Aksoy, Aytar, \& Kantez, 2017). Yapılmış olan çeşitli araştırmalarda mutluluk düzeyinin eğitim düzeyine göre anlamlı bir farklılık göstermediği bulunmuştur (Duran, 2016). Öte yandan, eğitim düzeyi yüksek olup çalışmayan bireylerin, eğitim düzeyi düşük olup çalışmayanlara göre daha mutsuz oldukları görülmüştür (Clark \& Oswold, 1994; Aa cited in; Dockery, 2010). TÜİK'in 2008 yılı verileriyle yaptığı araştırmanın sonucunda, eğitim düzeyi ile mutluluk arasında pozitif bir ilişki olduğu bulunmuştur (Kangal, 2013). Kişinin eğitim düzeyi arttıkça kazancı da artacaktır. Bireyin, kazancı, yaşı, sağlığ, medeni durumu ve hane halkı geliri konusundaki memnuniyeti yaşam memnuniyetini pozitif yönde etkilemektedir (Çevik \& Korkmaz, 2014).

Araştırmamızın sonucunda, ev kadınlarının eğitim düzeylerine göre kişisel gelişim yönelimi düzeyleri arasında anlamlı bir farklılık bulunmuştur. Üniversite mezunu olan ev kadınlarının kişisel gelişim yönelimi düzeyi, ilkokul mezunu olan ev kadınlarının kişisel gelişim yönelimi düzeylerinden anlamlı olarak yüksek olduğu bulunmuştur. Yine, üniversite mezunu olan ev kadınlarının kişisel gelişim yönelimi düzeyleri, lise mezunu olan ev kadınlarının kişisel gelişim yönelimi düzeylerinden anlamlı olarak yüksek olduğu bulunmuştur. Kadınların eğitimi uluslararası düzeyde insani gelişmenin temel göstergelerinden biridir. Eğitim düzeyi yükseldikçe kadın daha önce "ev" ile sınırlı kalan ilgi, beceri ve bilgisini artırma şansı bulmaktadır. Çalışma yaşamına ve karar mekanizmalarına katılım olanakları artmaktadır. Kendi yaşamını olduğu kadar, sorumlu olduğu diğer insanların yaşamlarını da etkileyecek doğru kararları verebilecek düzeye gelmekte aynı zamanda sağlık hizmetlerine erişim ve kullanımı önemli ölçüde artmaktadır (Doğan, 2013). Dağlı \& Beyazsaçlı'nın (2010) yapmış oldukları araştırmanın sonucunda da üniversite mezunu olan bireylerin kendini gerçekleştirme düzeylerinin anlamlı olarak yüksek olduğu bulunmuştur.

Araştırmanın sonucunda, ev kadınlarının ekonomik gelirine göre kişisel gelişim yönelimi düzeyleri arasında anlamlı bir farklılık bulunmamıştır. Ancak, ekonomik gelire göre mutluluk düzeyleri arasında anlamlı bir farklılık bulunmuştur. Ekonomik geliri yüksek olan ev kadınlarının mutluluk düzeyleri, ekonomik geliri düşük olan ev kadınlarının mutluluk düzeylerinden anlamlı olarak yüksek olduğu bulunmuştur. Yine, ekonomik geliri orta olan ev kadınlarının mutluluk düzeyleri, ekonomik geliri düşük olan ev kadınlarının mutluluk düzeylerinden anlamlı olarak yüksek olduğu bulunmuştur. Kültürel ve sosyoekonomik yönden gelişmişlik düzeyleri farklı üç ilde (Kocaeli, Adıyaman ve Isparta) 2912 kadın ile yapılan araştırma sonuçlarına göre; kadının mutluluğunu etkileyen en önemli unsur refah seviyesi olarak açıklanmıştır (Korkmaz et al., 2015). Ekonomik durumu iyi olanlar, düşük ekonomik gelire sahip olanlara göre daha mutludurlar (Easterlin, 2001) ve kendini gerçekleştirme düzeyleri daha yüksek olabilmektedir (Dağlı \& Beyazsaçl1, 2010).

Araştırmamızın sonuçları genel olarak değerlendirildiğinde, çalışmayan ev kadınlarının, yaklaşık yarısı mutsuzdur. Ayrıca, ev kadınlarının yaklaşık yarısının kişisel gelişim yönelimi düzeyi düşük çıkmışır. Kadının geleneksek rollerine bağlı olarak yalnızca ev içinde kalmaları onları mutsuz edebilmektedir. Günümüzde, toplumsal cinsiyet rolleri açısından eşitlikçi bakış açısı önemli görünmektedir. Yani; kadın ve erkeğin, eğitim, iş, çalışma, aile, evlilik ve sosyal yaşamında sorumlulukları eşit şekilde paylaşmaları gerekir (Göksel Oflas, 2016). Kadın, çalışma yaşamının içine girdiğinde kendisini üretken birey olarak görecektir. $\mathrm{Bu}$ da kişisel gelişimine, kendini gerçekleştirmesine ve mutlu olmasına katkı sağlayacaktır. 
Araştırma sonucunda ulaşılan bulgular dikkate alınarak, daha sonra yapılabilecek araştırmalara katkı sağlayabilecek öneriler aşağıda belirtilmiştir:

1) Çalışmayan ev kadınların mutluluk düzeyinin düşük çıkması, birtakım önlemlerin alınmasını gerekli kılmaktadır. Bu önlemlerin başında hiç şüphesiz ki eğitim gelmektedir. Eğitim seviyesi yükseldikçe kadınların iş gücüne katılımı sağlanarak ekonomik ve sosyal alanda mutluluk düzeyleri arttırılabilir.

2) Araştırmamıza konu olan ev kadınlarının, eğitim düzeyine göre kişisel gelişim yönelimi düzeyleri karşılaştırılması sonucunda üniversite mezunu olan katılımcılar ile lise mezunu olanların arasında fark olduğu görülmüştür. Eğitimin önemine burada bir kez daha vurgu yapılarak, bundan sonra yapılacak olan çalışmalara araştırmacıların, "kadınların eğitim seviyesini yükseltmek için neler yapılabilir?" soruna cevap aramaları yararlı olacaktır.

3) Araştırmamız sonucunda çalışmayan kadınların büyük çoğunluğu çocukların bakımı için çalışmadıklarını bildirmişlerdir. Çocukların bakım yükünü erken yaşta alabilecek bir sistem kurularak çalışmayan ev kadınlarına iş imkânı sağlamak için gerekli düzenlemeler yapılabilir. Bu düzenlemelerin neler olacağı başlı başına bir araştırmanın konusu olabilir.

4) Araştırmamız sonucunda çalışmayan kadınlar, çocuklarının bakımı için çalışmadıklarını belirtmişlerdir. Bütün iş kurumlarında, kreşlerin zorunlu olması, kadının çalışma yaşamına katılmasında çok yararlı olacaktır.

5) Okulöncesi eğitimden başlayarak, bütün eğitim kademelerinde, toplumsal cinsiyete ilişkin ve kadınların çalışma yaşamına katılmasına ilişkin kalıp yargıların ortadan kaldırılmasında, okul psikolojik danışmanlarına ve öğretmenlere önemli görevler düşmektedir.

6) Ders kitaplarının, toplumsal cinsiyete ilişkin ve kadınların çalışma yaşamına katılmasına ilişkin kalıp yargıları ortadan kaldırılacak şekilde yeniden düzenlenmesi gerekmektedir.

\section{Extended Summary}

Extensively discussed in many fields in the literature, "self-improvement" is the process whereby individuals train themselves in emotional, social, and behavioral terms in the best way possible and fulfill their existing potential at a high level (Aksoy, Aytar \& Kantez, 2017). Self-improvement could be defined as an individual's lifetime development through the effective use of his or her potential, abilities, and resources in order to become an individual with an adult ego (Balaban \& Çakmak, 2016). Self-actualization, on the other hand, refers to the individual need to use one's all abilities and improve their hidden talents to maintain their life, a tendency that exists in every individual and is there since birth (Aluş, 2016). A person attains happiness if they fulfill their dreams and achieve their goals by total use of their abilities. Happy individuals have high levels of life satisfaction and positive affectivity with relatively less negative affectivity.

It is vital for all, both men and women alike, to make use of their abilities, work and be productive. However, in today's world, women are still not given equal opportunities for education and employment. Most girls are unfortunately forced to marry and have children at a young age, which prevents women from gaining strength (Küçük, 2015). Moreover, women are usually offered jobs in low-wage industries, which is a particular demotivating factor for women. On the other hand, day care or school hours for children sometimes do not fit mothers' work hours and issues like elderly care are still considered a responsibility of women, which are other factors that draw women away from work life (Iş1k Erol, 2015). In addition to children, elderly and patients who are incapable of self-care, most women also cater to the caring needs of their husbands, who are perfectly capable of performing self-care (Bhasin, 2003; Korkmaz \& Korkut, 2012).

Research shows that psychological stress and depressive symptoms are more common among unemployed women. Working has health promoting effect (Dökmen, 2003, 2009). Wage labor has a positive impact on women's mood (Çilli et al., 2004). Being employed helps an individual come into existence and provides life satisfaction by the use of their talents and skills. Research conducted in high-income countries demonstrate that women's participation in work increases their life expectancy, reduces mortality, and improves mental and physical health (Türkdoğan \& Duru, 2012). 
There is ample research examining women's participation in paid labor. Many of such studies deal with its economic aspects like economic development of countries. The present study has been guided by the relative scarcity of research dealing with the psychological status of unemployed women. It aims to examine the levels of happiness and self-improvement tendencies of unemployed housewives.

This is a descriptive study aiming to examine whether the levels of happiness and self-improvement tendencies of unemployed housewives significantly differ according to certain personal variables. Selected using "convenient sampling", the study group consists of 321 housewives who were unemployed. The data was collected using the "Oxford Happiness Inventory" (short version), "Self-Improvement Tendency Scale", and a "Personal Information Form", for which all validity and reliability studies have been performed. SPSS 21 software pack was used for data analysis, for which One-Way Analysis of Variance (ANOVA), and Tukey Test were performed with a significance level of .05 .

According to the study results, the following reasons were identified for unemployment among housewives: for looking after kids; due to reluctance to work; because of the husband's unwillingness to allow his wife to work; since working is not deemed proper for women in traditional mentality; due to lack of jobs, and other reasons. The results revealed that $49.1 \%$ of the housewives have low levels of happiness, while $50.9 \%$ have high happiness levels, meaning that the housewives have similar levels of happiness. On the other hand, $40.2 \%$ of the housewives have low levels of self-improvement tendencies, while the levels are high for $59.8 \%$.

No significant difference was detected between the housewives' happiness levels according to their education levels. Yet, their levels of self-improvement tendencies significantly differ with their education levels. The housewives who graduated from a university have significantly higher levels of self-improvement tendencies than the primary school graduates. University graduates were also found to have significantly higher levels of selfimprovement tendencies when compared to the housewives who graduated from high schools.

No significant difference was detected between the housewives' self-improvement tendencies levels according to their economic income. Yet, their levels of the happiness significantly differ with their economic income. Housewives with a medium level of economic income were found to have significantly higher happiness levels than the housewives with low levels of economic income. Similarly, housewives with high economic income are significantly happier than those with low income levels.

An overall review of our study results reveals that about half of unemployed housewives are unhappy. Also, around half of these housewives were found to have low levels of self-improvement tendencies. Being bound to home as required by their traditional roles may make women unhappy. In modern life, egalitarian view has gained significance in terms of gender roles, which means that women and men should have an equal share in the responsibilities regarding education, employment, work, family, marriage, and social life. Women see themselves as productive individuals once they participate in work life, which would contribute to their personal growth, selfactualization, and happiness. 


\section{Kaynakça / References}

Aksoy, A. B., Güngör Aytar, B. \& Kaytez, N. (2017). Üniversite öğrencilerinin mutluluk ve alçakgönüllülük düzeylerinin bazı değişkenlere göre incelenmesi, Kastamonu Ĕ̈itim Dergisi, 25 (3), 1119-1132.

Alp, A. (2007). Yeni çalışma biçimleri ve değişen aile yapısı bağlamında çalışan kadınlar. (Yayınlanmamış Tezsiz Yüksek Lisans Projesi). Dokuz Eylül Üniversitesi, İzmir.

Aluş, Y. (2016). Türk ailesinde eşler arası mutluluk algısı ve beklentileri: Sakarya ili örneği (Yayınlanmamış Doktora Tezi). Sakarya Üniversitesi, Sakarya.

Amparado, M. J., Javier, P. M. C., Pomar, E. J. E., Aquino-Malabanan, M. G., \& Landicho, L. C. (2014). Self-actualization of married and unmarried among middle aged professionals. International Journal of Academic Research in Psychology, 1 (2), 17-24.

Arapkirlioğlu, H., \& Tankız, D. (2011). Müzik öğretmenliği programı özel yetenek sınavlarında alan ve yerleştirme puanlarının karşılaştırılması. E-International Journal of Educational Research, 2 (4), 55-69.

Balaban Ö., \& Çakmak, D. (2016). Üniversite öğrencilerinin kişisel gelişim eğitimlerine yönelik algılarının incelenmesi, Sakarya Üniversitesi İktisat Dergisi, 5 (1), 1-17.

Bhasin, K. (2003). Toplumsal cinsiyet bize yüklenen roller (Çev: K. Ay). İstanbul: Kadınlarla Dayanışma Vakfı Yayınları.

Bingöl, O. (2014). Toplumsal cinsiyet olgusu ve türkiye'de kadınlık, KMÜ Sosyal ve Ekonomik Araştırmalar Dergisi, 16 (Özel sayı 1), 108-114.

Bülbül, S. \& Giray, S. (2011). Sosyodemografik özellikler ile mutluluk algısı arasındaki ilişki yapısının analizi, Ege Akademik Baklş Dergisi, 11, 113-123.

Büyüköztürk, Ş., Kılıç Çakmak, E. Akgün,Ö. E. Karadeniz, Ş. \& Demirel, F. (2015). Bilimsel araştırma yöntemleri. Ankara: Pegem Akademi.

Ciccarelli, S. K., \& White, J. N. (2015). Psychology, an exploration. Boston: Pearson Education.

Çelik, Ö. (2008). Ataerkil sistem bağlamında toplumsal cinsiyet ve cinsiyet rollerinin benimsenmesi (Yüksek Lisans Tezi). Gazi Üniversitesi, Ankara.

Çevik, N., \& Korkmaz, O. (2014). Türkiye'de yaşam doyumu ve iş doyumu arasındaki ilişkinin iki değişkenli sıralı probit model analizi. Niğde Üniversitesi İ̈BF Dergisi,7 (1), 126-145.

Çilli A. S., Kaya, N. Bodur, S. Özkan, İ., \& Kucur, R. (2004). Ev kadınlarında ve çalışan evli kadınlarda psikolojik belirtilerin karşılaştırılması. Konya Genel Tip Dergisi, 14 (19), 1-5.

Dağlı G. ve Beyazsaçlı, M. (2010). Ana-baba tutumu ve kendini gerçekleştirme düzeyleri arasındaki ilişkinin değerlendirilmesi. Akdeniz Ĕ̈itim Araştırmaları Dergisi, 7,1-16.

Diener, E. (1984). Subjective well-being. Psychological Bulletin, 95 (3), 542-575.

Diener, E. (1994). Assessing subjective well-being: progress and opportunities. Social Indicators Research, 31 (2), 103-157.

Dikmen, A. A. (1995). İş doyumu ve yaşam doyumu ilişkisi. Ankara Üniversitesi Siyasal Bilgiler Fakültesi Dergisi, 3 (4), 115140.

Dockery, A. M. (2010). Education and happiness in the school-to-work transition. Australia: Published by National Centre for Vocational Education Research (NCVER).

Doğan, T. \& Çötok-Akıncı, N. (2011). Oxford mutluluk ölçeği kısa formunun Türkçe uyarlaması: geçerlik ve güvenirlik çalışması. Türk Psikolojik Danışma ve Rehberlik Dergisi, 4 (36), 165-172.

Doğan, T. (2013). Beş faktör kişilik özellikleri ve öznel iyi oluş. Doğuş Üniversitesi Dergisi, 14 (1), 56-64.

Dökmen, Z. (2003). Çalışma durumları farklı üç grup kadında ruh sağlığı,kontrol odağı inancı ve cinsiyet rolü. Türk Psikoloji Dergisi, 18(51), 111-124.

Dökmen, Z. (2009). Menopoz, beden imgesi ve ruh sağlı̆̆ı. Türk Psikoloji Yazılarl, 12 (24), 41-55.

Duran, A. (2016). Okul yöneticilerinin mutluluk düzeylerinin öz-yeterlikleriyle ilişkisi (Amasya ili örneği). (Yayınlanmamış Yüksek Lisans Tezi). Gaziosmanpaşa Üniversitesi, Tokat.

Easterlin, R. A. (2001). Income and happiness: towards a unified theory. The Economic Journal,111, 465-484.

Ergöl, Ş., Koç, G., Eroğlu, K. \& Taşkın, L. (2012). Türkiye'de kadın araştırma görevlilerinin ev ve iş yaşamlarında karşılaştıkları güçlükler. Yüksekögretim ve Bilim Dergisi, 2 (1), 43-49.

Eryılmaz, A. (2010). Ergenlerde öznel iyi oluşu artırma stratejilerini kullanma ile akademik motivasyon arasındaki ilişki. Klinik Psikiyatri, 13, 77-84.

Frager, R. \& Fadiman, J. (1984). Personality and personal growth. New York: Harper Colins Publishers.

Gladding, S. T. (2013). Psikolojik danışma, kapsaml bir meslek (Çev Ed: N. Voltan-Acar). Ankara: Nobel Yayın.

Golding, J. M. \& Singer, J. L. (1983). Patterns of inner experience: daydreaming styles, depressive moods and sex roles. Journal of Personality and Social Psychology, 45 (3), 663-675.

Göksel-Oflas, S. (2016). Üniversite öğrencilerinin psikolojik dayanıklllı düzeylerinin toplumsal cinsiyet rollerine, kültürlerarası duyarlllığa ve risk faktörlerine göre yordanması (Yayınlanmamış Yüksek Lisans Tezi). Yıldız Teknik Üniversitesi, İstanbul.

Güçray, S. (2009). Feminist terapi ve psikolojik danışma: Kültürel dönüşüm ve köklü toplumsal değişimlerin bir sonucu olarak gelişimsel bir perspektif (ss. 99-139). Gelişen psikolojik danışma ve rehberlik (Ed: F. Korkut-Owen, R. Özyürek, \& D. W. Owen). Ankara: Nobel Yayın.

Işık-Erol, S. (2015). Türkiye'de kadının çalışma hayatına katılımının belirleyicileri. Gazi Üniversitesi Sosyal Bilimler Dergisi, 2 (3), 1-22.

İşgücü Piyasası Araştırma Raporu (2015). Erişim adresi: https://media.iskur.gov.tr/14908/2015-i-donem-turkiye-raporu.pdf 
Kangal A. (2013). Mutluluk üzerine kavramsal bir değerlendirme ve Türk hane halkı için bazı sonuçlar. Elektronik Sosyal Bilimler Dergisi, 12 (44), 214-233.

Kaya, N. (2017). Kırsal ve kentsel alanda yaşayan evli kadınların evlilik uyumu, evlilik doyumu ve ilişkilerde mutluluk düzeylerinin karşılaştırılması ve incelenmesi (Yayınlanmamış Yüksek Lisans Tezi). İstanbul Ticaret Üniversitesi, İstanbul.

Kholasezadeh Gh., Vaseghi H , Ahmadi N, \& Abedinzadeh M. (2012). Comparing the mental health of housewives and day shift working women in Yazd County, Iran, 2010. JOHE, 1 (1), 29-36.

Kılıç, D. \& Ö̈ztürk, S. (2014). Türkiye'de kadınların işgücüne katılımı önündeki engeller ve çözüm yolları: bir ampirik uygulama. Amme İdaresi Dergisi, 47 (1),107-130.

Kim, H. (1998). Do employed and nonemployed Korean mothers experience different levels of psychological well-being in relation to their gender role attitudes and role qualities? Sex Roles, 38 (11), 915-932.

Korkmaz, A. \& Korkut, G. (2012). Türkiye'de kadının işgücüne katılımının belirleyicileri. Süleyman Demirel Üniversitesi İktisadi ve Ídari Bilimler Fakültesi Dergisi, 17 (2),41-65.

Korkmaz M., Germir, H. N., Yücel, A. S. \& Gürkan, A. (2015). Yaşam memnuniyeti üzerinde etkili olan sosyodemografik bileşenler üzerine bir analiz. Uluslar arası Hakemli Psikiyatri ve Psikoloji Araştırmaları Dergisi, 3 (2), 78-111.

Kuzgun, Y., \& Sevim, S. (2004). Kadınların çalışmasına karşı tutum ve dini yönelim arasındaki ilişki. Ankara Üniversitesi Eğitim Bilimleri Fakültesi Dergisi, 37 (1), 14-27.

Küçük, M. (2015). Çalışma hayatında kadınlar ve karşılaştıkları sorunlar: bir işverene bağlı olarak çalışan emekçi kadınlara ilişkin bir araştırma. Ekonomi Bilimleri Dergisi, 7(1), 1-17.

Liebert, R. M. \& Spiegler, M. D. (1990). Personality. California: Brooks/Cole Publishing Company.

Nevill, D. D. (1977). Sex roles and personality correlates. Human Relations, 38 (8), 751-759.

Özaslan, G. (2018). The essential meaning of self-actualization via principalship: A phenomenological study. Journal of Qualitative Research in Education, 6 (2), 9-24.

Özaydın, M., \& Özdemir, Ö. (2014). Çalışanların bireysel özelliklerinin iş tatmini üzerindeki etkileri: bir kamu bankası örneği. Işletme Araştırmaları Dergisi, 6 (1), 251-281.

Renner, T., \& Feldman, R. S. (2013). PsychSmart. New York: McGraw-Hill.

Sevindik, D. (2015). Orta yaş dönemi bireylerde dindarlık- mutluluk ilişkisi: Denizli örneği (Yayınlanmamış Yüksek Lisans Tezi). Süleyman Demirel Üniversitesi, Isparta.

Sharf, R. S. (2014). Psikoterapi ve psikolojik danışma kuramları (Çev Ed: N. Voltan-Acar). Ankara: Nobel.

Şahin, Ş. (2008). Beden eğitimi öğretmenlerinin tükenmişlik ve yaşam doyumu düzeyleri (Yayımlanmamış Yüksek Lisans Tezi). Mersin Üniversitesi, Mersin.

Taş, İ. (2011). Öğretmenlerde yaşamın anlamı yaşam doyumu sosyal karşılaşstırma ve iç-dış kontrol odağının çeşitli değişkenler açısından incelenmesi (Yayımlanmamış Yüksek Lisans Tezi). Sakarya Üniversitesi, Sakarya.

Tatlı, H., \& Koç, B. (2017). Çalışan kadın bakış açısıyla kadınların iş ve aile yaşamında karşılaştığı sorunlar hakkında bir uygulama. Íktisadiyat, 1(1), 145-170.

Taylor, S. E., Peplau, L. A., \& Sears, D. O. (2012). Sosyal psikoloji (Çev: A. Dönmez). Ankara: İmge.

Turan, N. (2018). Çalışma mutluluğu: kavram ve kapsam. Uludağ Journal of Economy and Society / B.U.Ü. Iktisadi ve İdari Bilimler Fakültesi Dergisi, 37 (1), 169-212.

Türkdoğan T., \& Duru, E. (2012). Üniversite öğrencilerinde öznel iyi oluşun yordanmasında temel ihtiyaçların karşılanmasının rolü. Kuram ve Uygulamada Eğitim Bilimleri Dergisi, 12 (4), 2429-2446.

Türkiye İstatistik Kurumu (TÜIK). (2016). İstatistiklerle kadın. Sayı: 24643. Erişim adresi: http://www.tuik.gov.tr

Ünal, Ö. A., \& Şahin, M. (2013). Lise öğrencilerinin yaşam doyumlarının bazı değişkenlere göre yordanması. Cumhuriyet International Journal of Education (CIJE), 2 (3), 46-63.

Weiten, W., Hammer, Y. H., \& Dunn, D. S. (2016). Psikoloji ve çağdaş yaşam, insan uyumu (Çev Ed: F. E. İkiz). Ankara: Nobel.

Yalçın, İ. \& Malkoç, A. (2013). Kişisel gelişim yönelimi ölçeği II’nin Türkçeye uyarlanması ve psikometrik özellikleriin incelenmesi. Düşünen Adam, 26, 258-266.

Yıldırım, H. \& Işık, K. (2017). Çalışmayan evli kadınların sosyal destek düzeyleri ile yaşam doyumları arasındaki ilişki ve etkileyen faktörler. Konuralp Tip Dergisi, 9 (2):47-51

Yıldızoğlu, H., \& Burgaz, B. (2014). The relationship between school administrators' five factor personality traits and their conflict management style preferences. Hacettepe University Journal of Education, 29 (2), 295-310.

Zeren, F., \& Kılınç-Savrul, B. (2017). Kadınların işgücüne katılım oranı, ekonomik büyüme, işsizlik oranı ve kentleşme oranı arasındaki saklı koentegrasyon ilişkisinin araştırılması. Yönetim Bilimleri Dergisi, 15 (30), 87-103. 